\title{
Effect of Light and Temperature on the Quality of Sam-Pee Mango (Mangifera Indica) Juice
}

\author{
Sumate Tantratian $^{1 *}$, Wimonsri Siripattanakul ${ }^{1}$ and Thirawan Chanrittisen ${ }^{2}$ \\ ${ }^{1}$ Department of Food Technology, Faculty of Science, Chulalongkorn University, Bangkok 10330,Thailand \\ ${ }^{2}$ Agricultural Technology Research Institute, Rajamangala University of Technology Lanna, Lampang 52000, \\ Thailand \\ Email: Sumate.T@chula.ac.th
}

\begin{abstract}
Mango juice is rich in vitamins, carotenoids and polyphenols. The effects of temperature and fluorescent light during processing and storage affected the carotenoids content in juice. This study was aimed to evaluate the effects of these two effects on carotenoids and other chemical properties of Sam-pee mango juice filled in clear bottle during commercial handling. It was conducted by comparing the changes which were exposed to fluorescent light and dark room at different temperatures. The carotenoids content in mango juice exposed to light at room temperature was significantly lower than those stored in the dark. The storage temperature higher than $35^{\circ} \mathrm{C}$ caused rapid deterioration of carotenoids and color. It was found that the smallest changes occurred during storage at $4^{\circ} \mathrm{C}$. The refrigeration storage and ascorbic acid supplement provided juice with significantly higher in the amount of $\beta$-carotene and total carotenoids and less color changes in comparison with the other samples after stored for 24 weeks.
\end{abstract}

Keywords: Mango juice; temperature; fluorescent light; ascorbic acid; $\beta$-carotene; carotenoids

\section{Introduction}

The Sam-pee variety of mango is a local variety grown in the Northern part of Thailand. It can be grown in many types of soil and resists the harshness of the climate. The trees are growing from seed and it takes about 3 years for them to bare fruits. This variety is very productive but the fruits are small in size. The ripe fruits are of yellow color with a strong and pleasant aroma. The pulp of Sam-pee mango contains abundant juice. These characteristics are suitable for mango juice processing recommended by Yoonchalad et al [1].

Mango juice has been used as a convenient substitute for fresh fruits. Mango juice has high nutritive value with its rich vitamins, carotenoids, minerals, and polyphenols [2]. Mango juice is a good source of potassium but low in the amount of sodium. The mango juice is a rich source of antioxidants, due to the presence of high amount of carotenoids and polyphenols [3]. The carotenoids are pigments that provide orange or red color in plant tissues. They are reported as precursors in the synthesis of vitamin A. The $\beta$-carotene, which is one of carotenoids, also functions as an antioxidant and prevents the occurrence of free radicals [4]. The carotenoid content of mango juice was studied by a number of researchers. The study by Veda et al. [5] showed that $\beta$-carotene content in ripe mango ranged from $0.55 \pm 0.03 \mathrm{mg} / 100$ $\mathrm{g}$ in the Malgoa variety to $3.21 \pm 0.25 \mathrm{mg} / 100 \mathrm{~g}$ in the Badami variety. Bioaccessibility of $\beta$-carotene ranged from $24.5 \%$ in Badami to $39.1 \%$ in Raspuri varieties of mango. The carotenoid content of mango juice depended on the degree of ripening of the fruits selected and processing $[6,7]$. The mixing and blending were required when small batches could be prepared. The ascorbic acid content in the juice after processing was differently reported. The low content of ascorbic acid, $2.5 \mathrm{mg} / 100 \mathrm{~g}$, was found in USDA National Nutrient Database for standard Reference while $12.57 \mathrm{mg} / 100 \mathrm{ml}$ was reported in commercial mango juice from Iran [8].

The carotenoids are sensitive to heat and light. Fratianni et al. [9] reported that almost all carotenoids in orange juice were decreased by about $50 \%$ when heated at $85^{\circ} \mathrm{C}$ for 1 min of Microwave heating. The heating process for preservation of the mango juice could destroy the carotene. Chen et al. [10] reported that $\beta$-carotene can be changed by either isomerization from trans-isomer which is normal form into cis-isomer or oxidative degradation to form volatile compounds influencing the color change. 
Montgomery and Petropakis[11] also reported that the mango juice quality was changed by polyphenoloxidase resulting in change from bright yellow to dark yellow color. The color change during storage of fruit juice can be prevented by heat inactivation [12] and some food additives such as potassium metabisulfite, sodium metabisulfite, butylated hydroxy anisole (BHA), butylated hydroxy toluene (BHT), sorbic acid, and ascorbic acid [13]. Benjamin [14] reported that the stable color of peach juice occurred by adding ascorbic acid together with sulfite compounds.

The mango juice has advantages as rich in pro-vitamin A activity and antioxidant capacity. The degradation of carotenoids by oxidation is alleged to affect the mango juice quality. The quality of mango juice during storage has been scarcely reported in the recent past. The storage and handling conditions influenced by the wholesalers and retailers affected the quality of the juice. Post-processed juice could possibly be handled under some conditions affected the stability of carotenoids. During display, the mango juice might be exposed to the light, especially the fluorescent light. High temperature storage might happen, during the warehouse storage or on the shelf. The storage temperature in the midday in some places might reach $45^{\circ} \mathrm{C}$ or higher. In a retail store, it might be displayed in a refrigerator $\left(4^{\circ} \mathrm{C}\right)$ or in a room condition $\left(27-30^{\circ} \mathrm{C}\right)$. This study was aimed to evaluate the effects of fluorescent light and temperature on carotenoids and some chemical properties of Sam-pee mango juice during commercial handling.

\section{$2 \quad$ Materials and Methods}

\subsection{Preparation of Mango Juice}

Mango fruits, Sam-pee variety, were harvested from the plantation of the Agricultural Technology Research Institute, Lampang, Thailand. The fruits with specific gravity 1.00-1.015 were chosen to ripe by aging with sodium carbide in a cardboard box. The pulp of ripe mangoes was blended and added with water to make $25 \%$ mango pulp juice. The juice was adjusted with sugar and citric acid to $15^{\circ}$ brix and $0.4 \%$ TA [17]. The juice was heated to $80-85^{\circ} \mathrm{C}$ for $5 \mathrm{~min}$, then hot filled into clear glass bottles $(250$ $\mathrm{ml}$ ). It was pasteurized again in boiling water for $15 \mathrm{~min}$ then cooled to room temperature. The bottled juice was used for further experiments. The color, $\beta$-carotene and total carotenoids of mango juices during processing were determined.

\subsection{Effect of Fluorescent Light on Mango Juice Quality}

An amount of $0.05 \%$ of ascorbic acid was added to the juice prior to bottling and heat treatments. The bottled juice without ascorbic acid was kept in cupboards under ambient temperature in a dark environment. In addition, juice without and with $0.05 \%$ ascorbic acid, was stored under fluorescent light of 500-600 lux light intensity. They were stored for 24 weeks under ambient condition. The juice samples were randomly picked every 4 weeks and checked for color, ascorbic acid, non-enzymatic browning index, total carotenoids and beta carotene.

\subsection{Effect of Storage Temperature on Mango Juice Quality}

The bottled mango juice was kept under various temperatures namely $4 \pm 2^{\circ} \mathrm{C}$ (in a refrigerator), ambient temperature $\left(27-30^{\circ} \mathrm{C}\right.$ in a box) and $45^{\circ} \mathrm{C}$ (in an incubator). The bottled mango juice with $0.05 \%$ ascorbic acid was kept in a refrigerator $\left(4 \pm 2^{\circ} \mathrm{C}\right)$. They were stored for 24 weeks. The juice samples were checked for color, ascorbic acid, non-enzymatic browning index, total carotenoids, and $\beta$-carotene.

\subsection{Determination of the Physical and Chemical Components}

The juice samples were subjected to color determination using Minolta ${ }^{\circledR}$ CR-300. The color was characterized using $\left(\mathrm{L}^{*}, \mathrm{a}^{*}, \mathrm{~b}^{*}\right)$ units. The $\mathrm{pH}$ was measured with $\mathrm{pH}$ meter, Schott CG825. The titratable acidity was determined according to AOAC [18]. The total carotenoids and $\beta$-carotene were determined according to Ranganna [19]. The carotenoids from mango juice were extracted using acetone then followed with petroleum ether extraction. $\mathrm{Na}_{2} \mathrm{SO}_{4}$ was applied to remove moisture from petroleum 
ether fraction. The petroleum ether was removed in a rotary evaporator. The solid mass was treated to remove the fatty acid by saponification with $10 \% \mathrm{KOH}$ in methanol. Then, it was repeated with the petroleum extraction. The solid mass was solubilized. Total carotenoids were determined as the absorption at $453 \mathrm{~nm}$ using a spectrophotometer and $\beta$-carotene was determined using HPLC equipped with a C18 column and a photodiode array detector. The operation condition was using the mixture of acetonitrite : dichlorometane : methanol (50:30:20) as a mobile phase and flow rate of $1 \mathrm{ml} / \mathrm{min}$. The non-enzymatic browning indexes (NEBI) were determined by the changes in the absorbance at $420 \mathrm{~nm}$ $[20]$.

\subsection{Statistical Analysis}

The design of experiment was a completely randomized design (CRD). All experiments were repeated three times and were reported as the mean \pm standard deviation $( \pm \mathrm{SD})$. Statistical significance of difference between means or between treatments were determined using ANOVA with a significant difference between treatments set at $\mathrm{p}<0.05$ in all cases. The statistical analysis was done using SPSS statistical package version 17.

\section{$3 \quad$ Results and Discussion}

\subsection{Effects of Fluorescent Light on the Mango Juice Qualities}

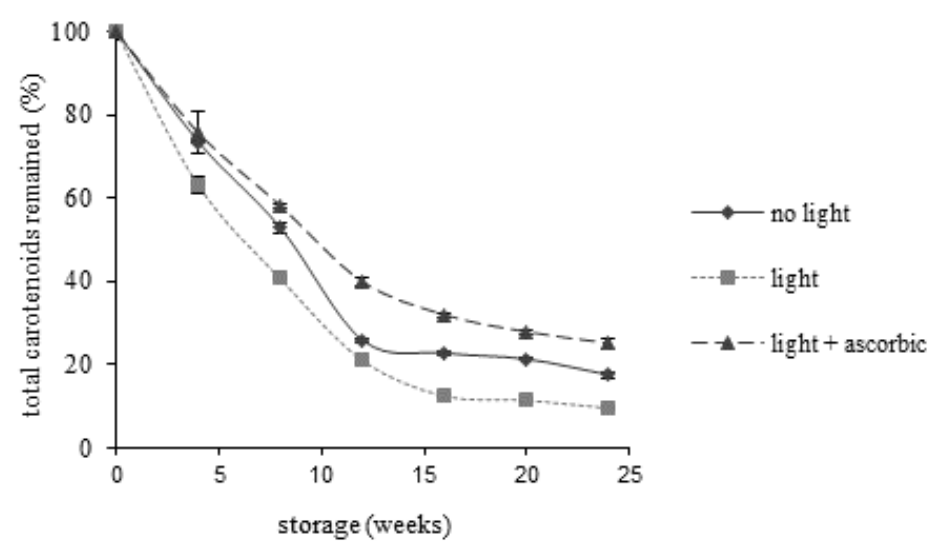

(a)

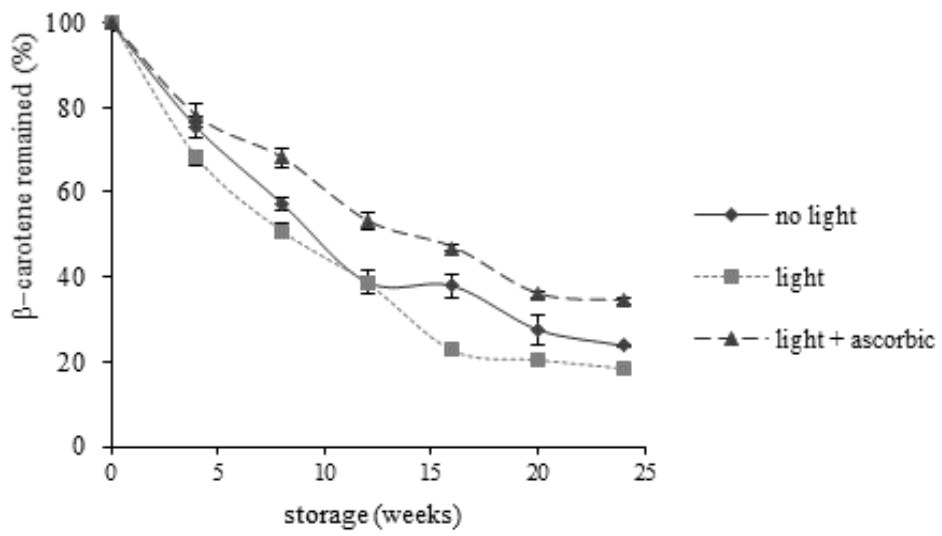

(b)

Figure 1. Changes in total carotenoids (a) and $\beta$-carotene (b) content of mango juices stored with fluorescent light and absence of light

The processed and bottled Sam-pee juice had characteristics of bright yellow juice with $\mathrm{pH} 3.47 \pm 0.08$, ascorbic acid content of $5.08 \pm 0.52 \mathrm{mg} / 100 \mathrm{ml}$, and total soluble solids of $15.50 \pm 0.25^{\circ} \mathrm{brix}$, total 
carotenoids of $766.99 \pm 19.10$ and $\beta$-carotene of $452.43 \pm 21.50 \mathrm{~g} / 100 \mathrm{ml}$. During storage at ambient temperature, the $\beta$-carotene and total carotenoids decreased very rapidly in the first 15 weeks (Fig. 1 ). The fluorescent light affected the amount of $\beta$-carotene and total carotenoids. The juice stored under fluorescent light contained less $\beta$-carotene and total carotenoids than those stored in the dark. The juice added with ascorbic acid had $\beta$-carotene and total carotenoids levels of $25.00 \pm 1.07$ and $34.26 \pm 0.82$, respectively, while the juice kept in the dark had levels of $23.79 \pm 0.35$ and $17.54 \pm 0.82 \%$ respectively. The addition of ascorbic acid to samples retarded the decrease of both $\beta$-carotene and total carotenoids as compared to samples without ascorbic acid added.

Many reports suggest that there were almost 30 types of carotenoids in mango. Among these carotenoids, the $\beta$-carotene was the main compound amounting to 30-50\% [21]. Each type of carotenoid was affected by the light differently $[22,23]$. The degradation of total carotenoids decreased rapidly in first 12-15 weeks of storage. Free radicals were generated from the reactions of the degradation causing a chain reaction. After 12 weeks of storage, the number of the sensitive carotenoids has significantly decreased.

Ascorbic acid content of mango juice gradually decreased in all treatments (Table 1). The ascorbic acid content in juice stored under fluorescent light decreased faster than juice stored in the dark (Table 2 ). In the juices without ascorbic acid added contained almost no ascorbic acid after 12 weeks. The destruction of ascorbic acid in mango juice during storage was also reported by Falade et al. [24].

The NEBI was increased in all conditions. The increasing of the NEBI was slowed during first 12 week storage, but after that it increased rapidly. The NEBI value of juices under fluorescent light was similar to the juice kept in the dark (Fig. 2). The addition of ascorbic acid $0.05 \%$ did not slow down the increase of the NEBI in the juice. The NEBI is the result of Maillard reactions and causes color changes and nutrition losses [25]. The end products formed by non-enzymic browning including organic acids, furans, furanones, ketones, cyclopentanones, pyranones and pyrroles, which many of these contributed to off flavor in the juices [26]. Falade et al. [24] suggested the $\mathrm{b}^{*}$ value and chroma were main indexes for color changes in mango juice during storage.

The $\mathrm{pH}$ of juices decreased during storage. The changes of $\mathrm{pH}$ in the juices kept in the dark and fluorescent light were not significantly different ( $>>0.05)$. They were in the range of 3.50 to 3.05. This agreed with the report from Alaka et al. [27] and Falade et al. [24].

Table 1. Ascorbic acid content in the mango juices during 24 week of storage under fluorescent light and absence

\begin{tabular}{c|c|c|c}
\hline \multirow{2}{*}{ Weeks } & \multicolumn{3}{|c}{ Ascorbic acid content $(\mathrm{mg} / 100 \mathrm{ml})$} \\
\cline { 2 - 4 } & Dark & Fluorescent light & $\begin{array}{c}\text { Ascorbic acid added/ } \\
\text { fluorescent light }\end{array}$ \\
\hline 0 & $5.54^{\mathrm{a}} \pm 0.03$ & $5.56^{\mathrm{a}} \pm 0.04$ & $34.97^{\mathrm{a}} \pm 0.33$ \\
\hline 4 & $4.20^{\mathrm{b}} \pm 0.05$ & $2.98^{\mathrm{b}} \pm 0.14$ & $33.50^{\mathrm{b}} \pm 0.11$ \\
\hline 8 & $3.10^{\mathrm{c}} \pm 0.11$ & $2.45^{\mathrm{c}} \pm 0.11$ & $32.08^{\mathrm{c}} \pm 0.34$ \\
\hline 12 & $1.08^{\mathrm{d}} \pm 0.11$ & $1.06^{\mathrm{d}} \pm 0.08$ & $31.76^{\mathrm{c}} \pm 0.11$ \\
\hline 16 & $0.62^{\mathrm{e}} \pm 0.02$ & $0.52^{\mathrm{e}} \pm 0.05$ & $30.61^{\mathrm{d}} \pm 0.37$ \\
\hline 20 & $0.54^{\mathrm{e}} \pm 0.08$ & $0.58^{\mathrm{e}} \pm 0.03$ & $28.99^{\mathrm{e}} \pm 0.08$ \\
\hline 24 & $0.44^{\mathrm{e}} \pm 0.09$ & $0.62^{\mathrm{e}} \pm 0.05$ & $26.24^{\mathrm{f}} \pm 0.34$ \\
\hline
\end{tabular}

Each value is the mean of three replications.

Means, in the same column, with different superscripts differ significantly at $\mathrm{p}<0.05$.

The juice with ascorbic acid added also had reduction of $\mathrm{pH}$, but the changes were slower than those in samples subjected to two other treatments (Fig. 2). This might be because of the addition of ascorbic acid to the juice. It has been reported that an increase in buffer capacity was found when concentration of ascorbic acid increased in the citrate buffer solution [22]. The ascorbic acid slowed the degradation of total carotenoids and $\beta$-carotene. The ascorbic acid could compete with the carotenoids in reacting with free radical molecules [23]. The additional of ascorbic acid to the juices slowed also down the changes of $\mathrm{pH}$ and amount of non-enzymic browning products. Hansawasdi et al. [28] studied on mango juice from Mangifera indica Linn. cv. Nahm-dawg-mai recommended the addition of $9 \%$ ascorbic acid to prevent deterioration of color. 


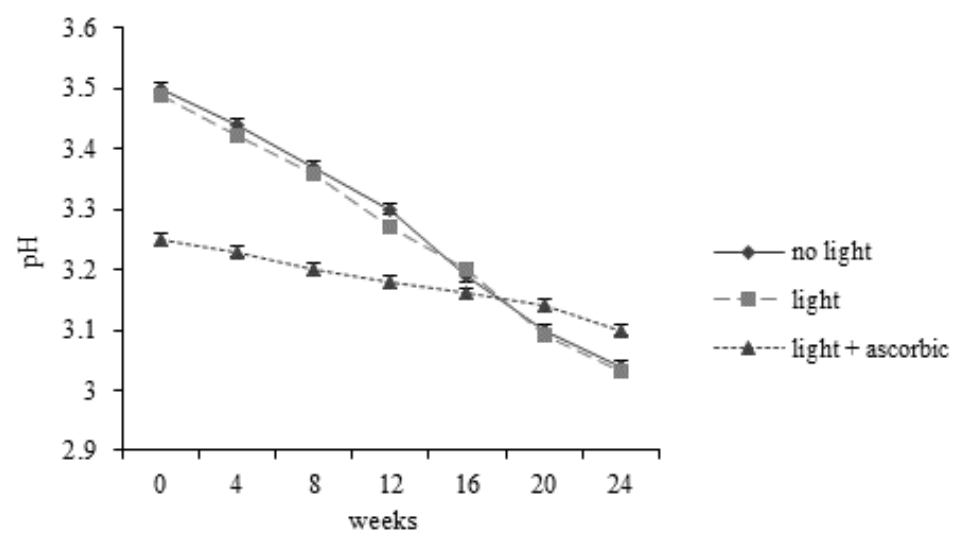

(a)

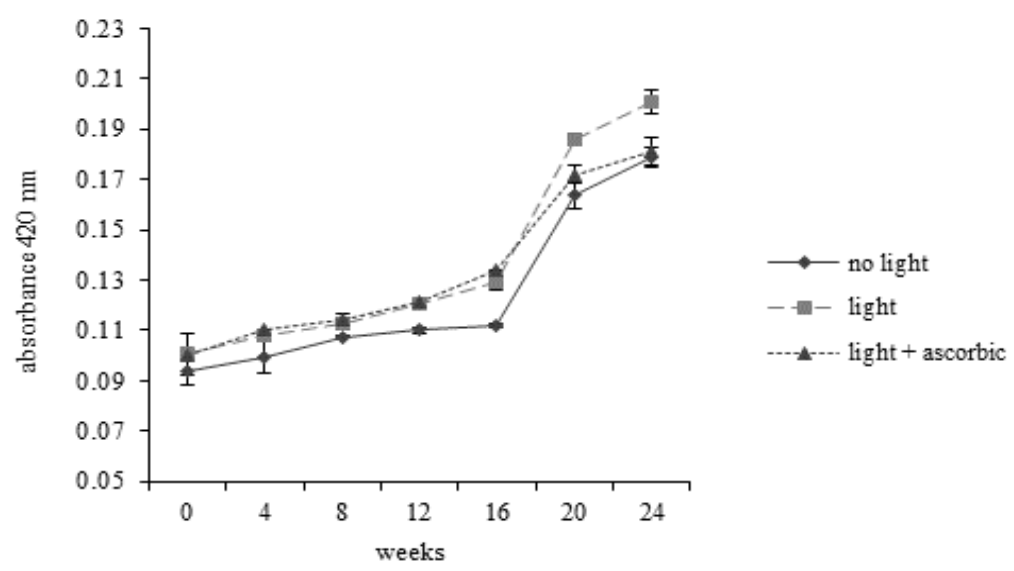

(b)

Figure 2. Changes of physico-chemical properties of mango juice, pH (a) and non-enzymic browning (b), stored 24 weeks under fluorescent light and absence of light.

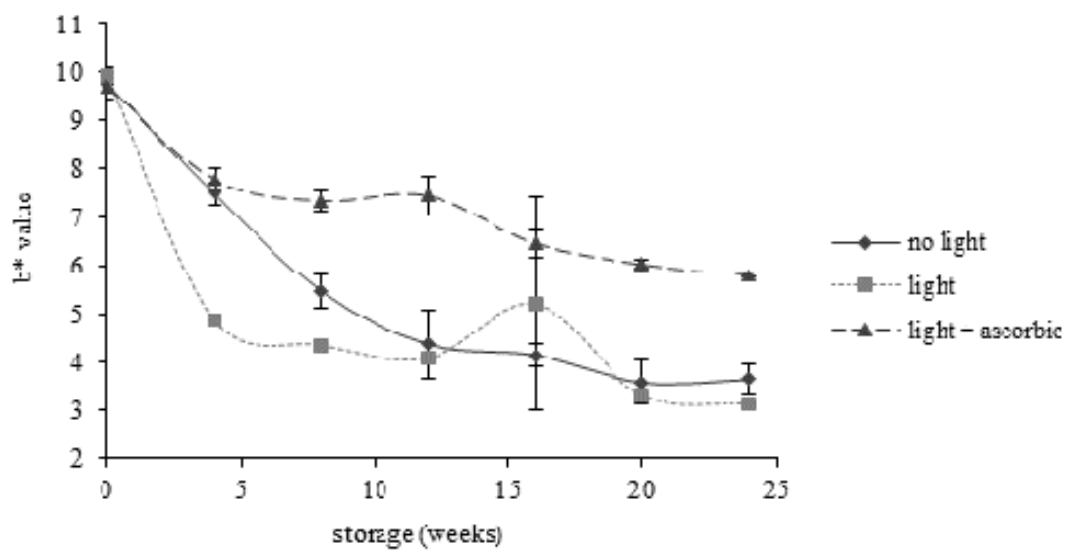

Figure 3. Changes of the yellowness ( $\left.b^{*}\right)$ of mango juice stored under fluorescent light

The color of juice stored under experimental conditions has not undergone a noticeable change under any of the treatments. However, the hue values changed during storage. The yellowish color in juices related to the $\beta$-cryptoxanthin and $\beta$-carotene [29]. The juices without ascorbic acid added had lightness $\left(\mathrm{L}^{*}\right)$ changed from 36 to 32 , redness $\left(\mathrm{a}^{*}\right)$ changed from -4 to -1.5 and yellowness $\left(\mathrm{b}^{*}\right)$ changed from 9.8 
to 3.5. The juice with ascorbic acid added shows a lesser change in yellow value than other samples (Figure 3). The lightness and redness were not significantly different in juices subjected to different treatments. That means the juice with ascorbic acid still had the color closer to the initial juice, while the color of the others samples might have become a little darker. The reduction in yellowness $\left(b^{*}\right.$ value) or the shift of yellow color toward light brown color related to the increase in NEBI [7]. The changes of color might have been caused by Maillard reaction, carotenoid oxidation and ascorbic acid oxidation [30, 31].

\subsection{Effects of Temperature on the Mango Juice Qualities}

The storage temperature affected the changes in mango juice quality. The higher temperature storage caused faster changes in chemical composition of juices. The ascorbic acid content in mango juice was depleted to a level lower than $1.0 \mathrm{mg} / 100 \mathrm{ml}$ after 8,12 and 16 weeks when stored at $45^{\circ} \mathrm{C}$, ambient and $4^{\circ} \mathrm{C}$, respectively. The ascorbic acid content of juice remained high in the mango juice added with $0.05 \%$ ascorbic acid. This remaining ascorbic acid could prevent the oxidization of the total carotenoids contained in the juices (Table 2). The $\mathrm{pH}$ of the juice with added ascorbic acid was stable after 16 weeks of storage (Fig. 4a), while the $\mathrm{pH}$ of juice without addition of ascorbic acid changed from 3.5 to less than 3.0 when stored at $45^{\circ} \mathrm{C}$.

Table 2. Ascorbic acid content $(\mathrm{mg} / 100 \mathrm{ml})$ in mango juice during 24 weeks storage at different temperatures.

\begin{tabular}{c|c|c|c|c}
\hline \multirow{2}{*}{ Weeks } & \multicolumn{4}{|c}{ Storage conditions } \\
\cline { 2 - 5 } & $4^{\circ} \mathrm{C}$ & $4^{\circ} \mathrm{C}+0.05 \%$ ascorbic acid & Ambient temperature $\left(27-30^{\circ} \mathrm{C}\right)$ & $45^{\circ} \mathrm{C}$ \\
\hline 0 & $4.61^{\mathrm{a}} \pm 0.05$ & $34.56^{\mathrm{a}} \pm 0.13$ & $4.69^{\mathrm{a}} \pm 0.08$ & $4.59^{\mathrm{a}} \pm 0.06$ \\
\hline 4 & $3.98^{\mathrm{b}} \pm 0.17$ & $31.47^{\mathrm{b}} \pm 0.49$ & $3.61^{\mathrm{b}} \pm 0.281$ & $3.12^{\mathrm{b}} \pm 0.08$ \\
\hline 8 & $3.17^{\mathrm{c}} \pm 0.13$ & $30.42^{\mathrm{c}} \pm 0.37$ & $2.44^{\mathrm{c}} \pm 0.14$ & $1.47^{\mathrm{c}} \pm 0.16$ \\
\hline 12 & $2.10^{\mathrm{d}} \pm 0.03$ & $28.73^{\mathrm{d}} \pm 0.81$ & $1.19^{\mathrm{d}} \pm 0.24$ & $0.76^{\mathrm{d}} \pm 0.02$ \\
\hline 16 & $1.51^{\mathrm{e}} \pm 0.17$ & $27.85^{\mathrm{d}, \mathrm{e}} \pm 0.27$ & $0.80^{\mathrm{e}} \pm 0.08$ & $0.50^{\mathrm{e}} \pm 0.01$ \\
\hline 20 & $0.52^{\mathrm{f}} \pm 0.01$ & $27.45^{\mathrm{e}} \pm 0.24$ & $0.68^{\mathrm{f}, \mathrm{g}}+0.04$ & $0.24^{\mathrm{f}} \pm 0.06$ \\
\hline 24 & $0.42^{\mathrm{g}} \pm 0.06$ & $24.61^{\mathrm{e}} \pm 0.50$ & $0.63^{\mathrm{f}, \mathrm{g}} \pm 0.06$ & $0.16^{\mathrm{g}} \pm 0.03$ \\
\hline
\end{tabular}

Each value was the mean for three replications.

Means, in the same column, with different superscripts were significantly different at $\mathrm{p}<0.05$.

The NEBI was also affected by the storage temperature. The rapidly increased in NEBI was found in the juice stored at $45^{\circ} \mathrm{C}$, while the changes in other condition juices were similarly (Fig. $4 \mathrm{~b}$ ). The results agreed with the report of Lee and Chen [32] that a higher incidence of non-enzymatic browning reaction was found in the juice stored at higher temperature.

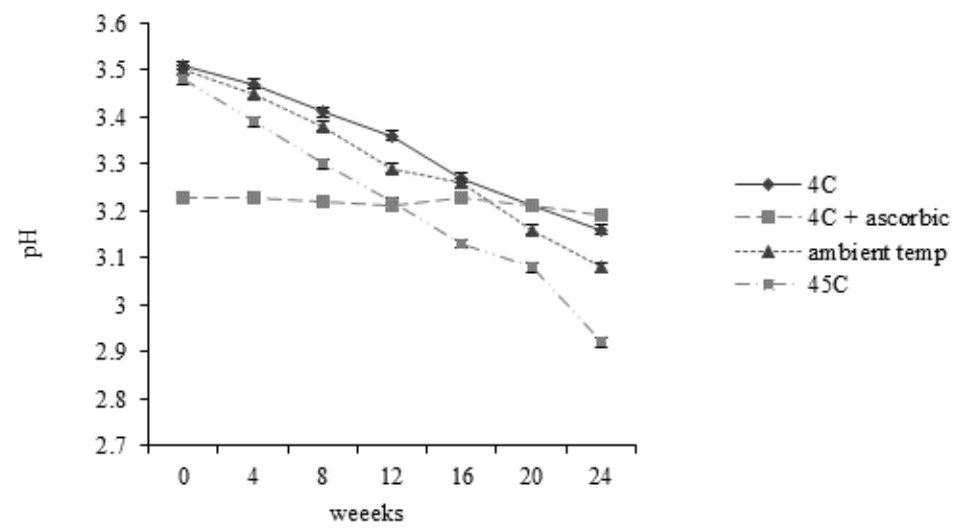

(a) 


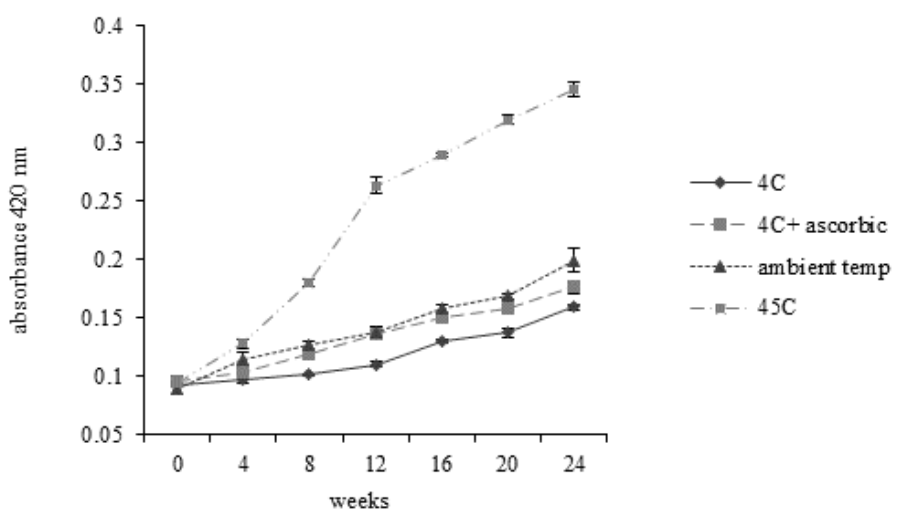

(b)

Figure 4. Effects of temperature on physico-chemical properties of mango juice stored under fluorescent light and absence of light for 24 weeks.

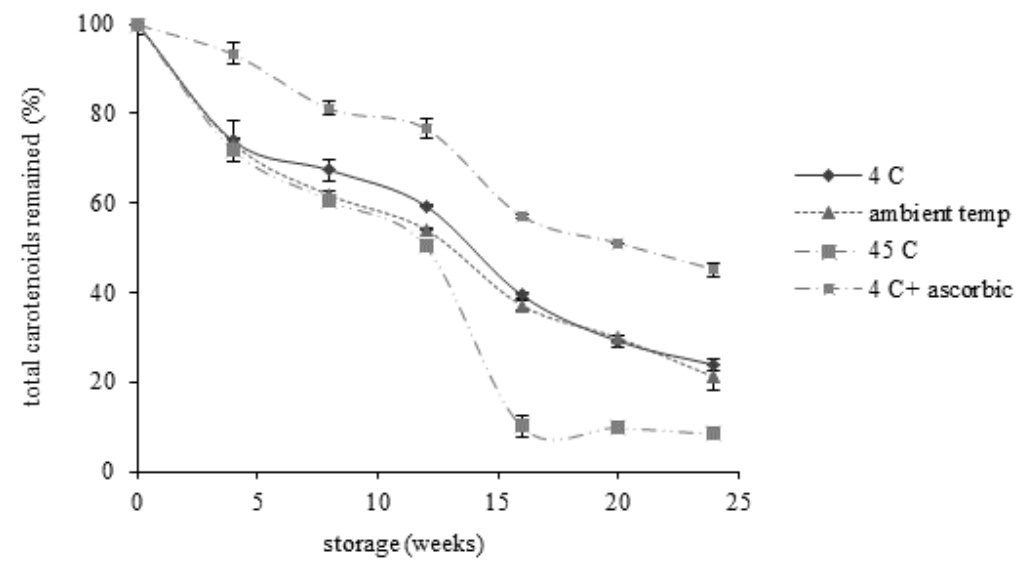

(a)

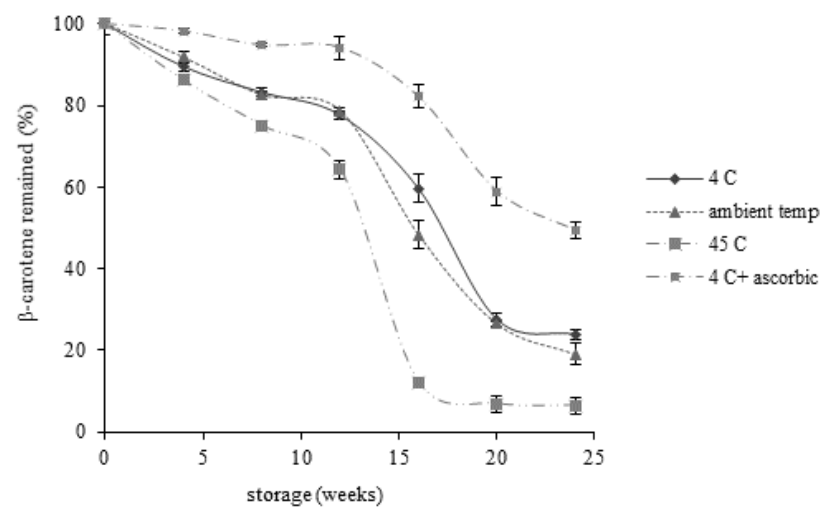

(b)

Figure 5. Effects of temperature on total carotenoids (a) and $\beta$-carotene (b) in mango juice stored under fluorescent light

The carotenoids content of mango juice were degraded by high storage temperatures. The total carotenoids and $\beta$-carotene was remained about $10 \%$ within 15 weeks storage under warehouse simulation temperature, $45^{\circ} \mathrm{C}$ (Fig. 5). The degradation of carotenoids was almost the same in the samples without ascorbic supplemented when stored under refrigeration and ambient conditions. The amount of $20 \%$ of total carotenoids and $\beta$-carotene were remained in juices after 24 week storage under 
$4^{\circ} \mathrm{C}$ and ambient. The addition of ascorbic acid to the juice slowed down the degradation. The remains of the total carotenoids and $\beta$-carotene were $50 \%$.

The changes in total carotenoids were faster decreased when storing pasteurized orange juice in the temperature higher than $35^{\circ} \mathrm{C}$ [33], but a slight decrease was noticed during refrigeration [34]. Our data agreed only in the higher temperature condition. The composition, such as $\mathrm{pH}$, and type or structure of food matrix could be the factors that cause the variation in degradation [35].

The ascorbic acid also retarded the changes of yellowness. The storage at $4^{\circ} \mathrm{C}$ and ambient temperature were not much different from each other, but the yellowness decreased very fast in samples stored at $45^{\circ} \mathrm{C}$ (Fig. 6).

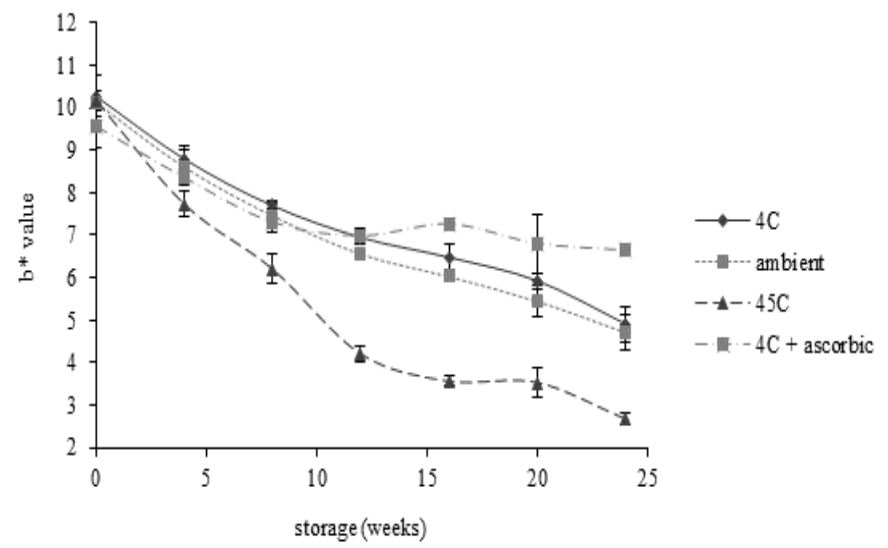

Figure 6. Effects of temperature on the Yellow value $\left(b^{*}\right)$ of the mango juice during storage under fluorescent light

The higher temperature also induced the degradation of $\beta$-carotene which agreed with Pesek and Warthesen [36]. The addition of ascorbic acid prevented the depletion of carotenoids significantly when the juice was kept at $4^{\circ} \mathrm{C}$ and under fluorescent light, which was the preferred condition for keeping the ready-to-drink juice.

\section{Conclusion}

Our data demonstrated that filling our mango juice in the clear bottles is preferable. The addition of ascorbic acid is necessary to slow down the degradation of carotenoids in mango juice, while storage temperature higher than $30^{\circ} \mathrm{C}$ should be avoid. The juice can be handled and stored under ambient or refrigeration condition for 15 weeks without lost in bright yellow color appearance and carotenoids content remains higher than $50 \%$ of initial amount. The juice can be displayed on the shelf with fluorescent light without speed up the degradation of carotenoids.

Acknowledgments. We are particularly grateful for the sponsorship from Thai government and Rajamangala University of Technology Lanna and the support from Agricultural Technology Research Institute. The preparation of this manuscript was possible with the assistance in editing of Dr. Juan L. Silva, a visiting professor, at Chulalongkorn University, Bangkok and a professor at Food Technology and Nutrition, Mississippi State University, Mississippi State, USA.

\section{References}

1. M., Yoonchalad, C., Babprasert, K., Thaveesuk, C. Hiranga and R., Jutaborn, "Sensory evaluation of canned mixed variety mango juice". Food. vol. 28 no.3, pp.179-189 (in Thai). 1998.

2. M, Masibo and Q. He, "Mango bioactive compounds and related nutraceutical properties - A review". Food Research International, vol. 25, pp. 346-370, 2009. 
3. A. Ravain, and D.C. Joshi, "Mango and it's by product utilization-A review". Trends Post Harvest Technology, vol. 74, pp 55-67, 2013.

4. G. Block, and L. Langseth, "Antioxidant vitamins and disease prevention". Food Technology, vol. 48, pp 80-84, 1994.

5. S. Veda, K. Platel and K. Srinivasan, "Varietal differences in the bioaccessibility of $\beta$-carotene from mango (Mangifera indica) and papaya (Carica papaya) fruits". Journal of Agricultural and Food Chemistry. vol. 55, no.19, pp 7931-7935, 2007.

6. R. C. Guarte, I. Pott, W. Muhlbauer, "Influence of drying parameters on $\beta$-carotene retention in mango leather". Fruits. vol. 60, no.4, pp 255-265, 2005.

7. V. Santhirasegaram, Z. Razali and C. Somasundram, "Effects of thermal treatment and sonication on quality attributes of Chokanan mango (Mangifera indica L.) juice". Ultrasonics Sonochemistry vol. 20, no. 5, pp 12761282, 2013.

8. R. Mahdavi, Z. Nikniaz, M. Rafraf, and A. Jouyban, "Determination and comparison of total-polyphenol and vitamin C contents of natural fresh and commercial fruit juice". Pakistan Journal of Nutrition. vol 9, pp 968-972, 2010.

9. A. Fratianni, L. Cinguanta, and G. Panfill, "Degradation of carotenoids in orange juice during microwave heating". LWT-Food Science and Technology vol.43, pp867-871, 2015.

10.B.H. Chen, T.M. Chen, and J.T. Chein, "Kinetic model for studying the isomerization of alpha and $\beta$-carotene during heating and illumination". Journal of Agriculture and Food Chemistry vol. 42, no. 11, pp 2931-2937, 1994.

11.M.W. Montgomery and H.J. Petropakis, "Inactivation of Bartlett pear polyphynoloxidase with heat in the presence of ascorbic acid". Journal of Food Science vol .45, no. 4, pp 1090-1100, 1980.

12.N. Nath, U. Siddaling and S. Ranganna, "Heat transfer characteristics and process requirements of hot-filled guava pulp". Journal of Food Technology. Vol. 18, no. 3, pp 317-326, 1983.

13.D.V. Sudhakar and S.B. Maini, "Stability of carotenoids during storage of mango pulp". Journal of Food Science and Technology. vol. 31, no. 3, pp 228-230, 1994.

14.B. Benjamin, "The role of ascorbic acid in food". Food Technology vol. 41, no. 11, pp 98-99. 1987.

15.R.C. Guarte, I. Pott and W. MuHlbauer, Influence of drying parameters on $\beta$-carotene retention in mango leather. Fruits. vol. 60, pp 255-265, 2005.

16.J.P. CHEN, C.Y. TAI and B.H. CHEN, "Effects of different drying treatments on the stability of carotenoids in Taiwanese mango (Mangifera indica L.)". Food. vol.100, no. 3, pp 1005-1010, 2007.

17.S. Tantratian, W. Siripattanakul, and T. Chanrittisen, "Conditions for ripening, processing and storage of Sampee mango juice". Journal of Science Research, Chulalongkorn University. vol. 5, no. 1, pp 51-59 (in Thai with Eng. Abs.), 2006.

18.AOAC, Official method of analysis of association of official analytical chemists. 16th ed. Washington D.C. 1995.

19.S. Ranganna, "Manual of Analysis of Fruit and Vegetable Products". 2nd ed. New Delhi; McGraw-Hill Publishing Company Limited. 1978.

20.E. Cohen, Y. Birk, C.H. Mannheim, and I.S. Saguy, "A rapid method to monitor quality of apple juice during thermal processing". LWT-Food Science and Technology., vol. 31, pp. 612-616, 1998.

21.M.P. Cano and A. de Begona, "Carotenoid and carotenoid ester composition in mango fruit as influenced by processing method". Journal of Agriculture and Food Chemistry. vol. 42, pp 2737-2742, 1994.

22.V. Vologovsky and N. Kim, "Ascorbic acid determination with an ion-sensitive field effect transistor-based peroxide biosensor". Analytica Chemica Acta. vol. 359, no. 1-2, pp 143-148, 1998.

23.M. Goldman, B. Horev and I. Saguy, "Decolourization of $\beta$-carotene in model system simulating dehydrated foods. Mechanism and kinetic principles". Journal of Food Science. vol. 48, pp 751-754, 1983.

24.K.O. Falade, S.O. Babalola, S.O.S. Akinyemi and A.A. Ogunlade, "Degradation of quality attributes of sweetened Julie and Ogbomoso mango juices during storage". European Food Research and Technology, vol. 218, pp 456-459, 2004.

25.I.M. Caminiti, F. Noci, A. Munoz, P. Whyte, D.J. Morgan, D.A. Cronin, and J.G. Lyng, "Impact of selected combinations of non-thermal processing technologies on the quality of an apple and cranberry juice blend". Food Chemistry, vol. 124, pp. 1387-1392, 2011.

26.S. Nagy, H.S. Lee, R.L. Rouseff, and J.C.C. Linn, "Nonenzymic browning of commercially canned and bottled grapefruit juice." Journal of Agriculture and Food Chemistry, vol. 46, pp 128-130, 1990. 
27.O.O. Alaka, J.O. Aina, and K.O. Falade, "Effect of storage conditions on the chemical attributes of Ogbomoso mango juice" European Food Research and Technology, vol. 218; pp 79-82, 2003.

28.C. Hansawasdi, P. Chaiprasart, and P. Meepayung, "Canned mango juice processing from Mangifera indica Linn. cv. Nahm-dawg-mai." Acta Horticulturae, vol. 820, pp 775-779, 2009.

29.A.J. Melendez-Martinez, I.M. Vicario and E.J. Heredia, "Review: analysis of carotenoids in orange juice". Journal of Food Composition and Analysis, vol. 20, pp 638-649, 2007

30.H.D Belitz and W. Grosh, Food chemistry. New York. Springer-Vertag Publishing, 1987.

31.J.R. Johnson, R. Braddock, and C.S. Chen, "Kinetics of ascorbic acid loss and nonenzymatic browning in orange juice serum: Experimental rate constants." Journal of Food Science, vol. 60, pp 502-504, 1995.

32.H.S. Lee, and C.S. Chen, "Rates of vitamin C loss and discoloration in clear orange juice concentrate during storage at temperature of $4-24 \mathrm{oC}$ ". Journal of Agriculture and Food Chemistry. vol. 46, no.11, pp 4723-4727, 1998.

33.S. Wibowo, L. Vervoort, J. Tomic, J. S. Santiago, L. Lemmens, A. Panozzo, T. Grauwet, M. Hendrickx, and A.V. Loey. "Colour and carotenoid changes of pasteurized orange juice during storage". Food Chemistry. vol. 171. pp.330-340,2015.

34.L. Vervoort, I. Van der Plancken, T. Grauwet, R.A.H.Timmermans, H.C. Mastwijk, A. M. Matser. "Comparing equivalent thermal, high pressure and pulsed electric field processes for mild pasteurization of orange juice. Part II: Impact on specifiec chemical and biochemical quality parameters". Innovative Food Science and Emerging Technologies. vol.12.pp466-477, 2011

35.C. Penicaud, N. Achir, C. Dhuique-Mayer, M. Dornier, Pl Bohuon. "Degradation of $\square$-carotene fruit and vegetable processing or storage: reaction mechanisms and kinetic aspects: a review". Fruits. Vol. 66, pp. 417-440, 2011

36.C.A. Pesek, and T.J. Warthesen, "Kinetic model for photoisomerization and concomitant photodegradation of $\beta$ carotene". Journal of Agriculture and Food Chemistry. vol. 38, pp1313-1315, 1990. 